\title{
EFFECT OF DRILL SPEED AND FEED MECHANISMS ON IN-ROW SEED SPACING ACCURACY OF RED BEET
}

\author{
Nikola Bilandžija, Goran Fabijanić, Stjepan Sito, Darko Kiš
}

Preliminary communication

The most significant factor for controlling root size of red beet is likely to be the density of seed plantings. Most red beet is produced by direct sowing with precision drills at an in-row spacing of 5 to $10 \mathrm{~cm}$, aiming at 30 to 70 plants per $\mathrm{m}^{2}$. The purpose of this research was to examine the effects of varied forward speed on in-row seed spacing distribution accuracy of red beet using different types of precision drills. It was found that an increase in the drill operating speed decreases drilling precision. The best in-row seed spacing distribution accuracy was determined at the speed of $0,83 \mathrm{~m} / \mathrm{s}$ with the pneumatic feed precision drill operated suction system, when $83,1 \%$ of seeds were laid at the $0,5 \div 1,5$ of the theoretical seed spacing. Inferior results were obtained with the belt feed mechanism at an operating speed of $1,81 \mathrm{~m} / \mathrm{s}$.

Keywords: drill forward speed; feed mechanism; precision drill; red beet; seed spacing accuracy

Utjecaj brzine kretanja i tehničkih izvedbi precizne sijačice na preciznost sjetve cikle unutar reda

Prethodno priopćenje

Veličina korjena cikle najviše ovisi o broju biljaka po jedinici površine (sklopu). U proizvodnji cikle večinom se koriste precizne sijačice podešene na razmak sjemena od 5 do $10 \mathrm{~cm}$ u redu, a radi dobivanja sklopa od 30 do 70 biljaka po $1 \mathrm{~m}^{2}$. Svrha istraživanja je bila utvrditi utjecaj različitih brzina kretanja preciznih sijačica različitih izvedbi na preciznost sjetve unutar reda. Utvrđeno je da se povećanjem brzine kretanja sijačice smanjuje preciznost sjetve. Najprecizniji razmak sjemena unutar reda postignut je s preciznom pneumatskom sijačicom s podtlakom pri brzini kretanja od $0,83 \mathrm{~m} / \mathrm{s}$, gdje je $83,1 \%$ sjemena bilo posijano unutar skupine od 0,5 do 1,5 od traženog (teoretskog) razmaka. U sjetvi s preciznom sijačicom s mehaničkim sijaćim uređajem s trakom pri brzini kretanja od $1,81 \mathrm{~m} / \mathrm{s}$ su dobiveni lošiji rezultati.

Ključne riječi: brzina sjetve; cikla; precizna sijačica; preciznost sjetve; princip rada sijačice

\section{Introduction}

Red beet (Beta vulgaris subsp. vulgaris var. conditiva) also known as beetroot and table beet belongs to the family Chenopodiaceae. It originated in Africa and was brought to Europe by the Romans [1]. Since then, the selection for traits such as a swollen root, deep colour, and sweetness, resulted in the development of the modern forms of this vegetable [2, 3]. Red beets are grown and consumed worldwide, but are most popular in Eastern Europe, Asia, the Mediterranean region, and the United States [2].The most significant factor for controlling root size of red beet is likely to be the spacing between plants, or the density of seed plantings. The challenge being is to maximise the production/yield of the desired root size group [4]. Benjamin et al. [5] noted that variation in plant weight increased with plant density, and found that when plant spacing was less than $5 \mathrm{~cm}$, self-thinning was more marked. The authors postulated that distance to the nearest plant (density) was more important than between row spacing. A maximum yield of small beets per unit area was achieved at higher plant densities, while maximum yield of large beets was achieved at lower plant densities. In red beet production, great attention is paid to sowing [6]. Uniform seed spacing results in an increased yield by minimizing competition between plants for available light, water, and nutrients [7].The main factors affecting performance of the drills are seed quality, presowing soil preparation, soil refinement, metering mechanism for seed and working speed. Since the early 1980s the ideal number and distribution of plants without singling cultivation is determined by sowing [8]. Mechanical and pneumatic precision drills are used to sow red beet. Both drills should meet the following requirements: sowing one seed, laying seed from as low a height as possible, laying seed to the precisely defined depth, pressing seed with loose soil and losing the soil above the seed to reduce water evaporation from soil [9]. Besides the drilling mechanism type, operating speed is an important factor for sowing quality, increase of productivity and cost effectiveness. Analysis of the literature data [10] indicates that with the effect of drill operating speed, the quality of red beet sowing should be reflected in several ways: uniform distribution of plants in a row, achievement of a defined number of plants per unit area, seed damage by drill mechanisms and seed laying depth. Another factor influencing the efficiency of red beet sowing is the quality of seed processing [11]. Seeds of vegetable crops differ greatly in their characteristics, of which size, shape, weight and seed admixtures are of special importance for the selection and application of drilling mechanisms. Results of laboratory investigations with carrot, red beet and lettuce seeds confirmed that an increase in sowing speed leads to poorer sowing quality of mechanical and pneumatic drilling mechanisms [12]. Uniform seed spacing is considered a fundamental factor in quality and yield for many crops and drill manufacturers continuously try to improve the accuracy in seed placement, according to the cultivation standard requirements [13]. Modern red beet production technology is based on single-germ seed, which can be mechanically obtained by segmentation of natural nodular seed. Such single-germ seed is calibrated and pelleted to obtain seed fractions of desired dimensions. Soil presowing preparation is carried out with combined cultivators, tilling only the seedbed to the depth of $4 \div 5$ $\mathrm{cm}$ in order to lay seeds on a naturally settled bed [14]. Analysis of research results indicates that the influence of drill operating speed on sowing quality is reflected in the uniformity of laying seeds within a row, between rows, 
whether seed damage occurs when passing through the drill working bodies and seed-laying depth [15]. Studies of the process of feeding seed into the drilling mechanism of mechanical drills have shown that the height of seed in seed hopper or seed chamber, affects the uniformity of filling the opening of the drilling mechanism [16]. Poorer filling of the drilling mechanisms opening is associated with changes in the strength of friction, which depend on the coefficient of sliding friction, coefficient of static friction and normal force. Homogenous crop stand with the least possible misses or doubles is heavily dependent upon the choice and adjustment of the right sowing machine [17]. The research objective was to find out which drilling mechanism enables better seed distribution, and how particular types of drilling mechanisms affect drilling precision with respect to operating speed.

\section{Material and methods}

Red beet was sown using drills with mechanical and pneumatic drilling mechanisms. The mechanical drilling mechanisms used here were a drill with the belt feed mechanism (BF) and a drill with cell wheel system (CF). A pneumatic drill with a vacuum suction system (VF) and a pneumatic drill with a compressed air system (PF) were used in this research. Precision drills were tested on the laboratory bench and on the plot field trial to determine in-row seed spacing distribution accuracy at the drilling speed of $0,83 \mathrm{~m} / \mathrm{s} ; 1,25 \mathrm{~m} / \mathrm{s} ; 1,44 \mathrm{~m} / \mathrm{s}$ and $1,81 \mathrm{~m} / \mathrm{s}$. After sowing at a particular speed, distance between sown seeds was measured along a length of $10 \mathrm{~m}$ for each drill row, with three repetitions.

The seed spacing descriptive parameters used in the analysis were divided into several groups of theoretical seed spacing: $0,0 \div 0,5 ; 0,5 \div 1,5 ; 1,5 \div 2,5$ and over 2,5 . The precision drills seed spacing uniformity were measured using methodology defined in ISO 7256/1 standard [18], in terms of distance between seeds in a furrow. For the ISO Miss index, the ISO Standard classifies "all spaces larger than 1,5 times the theoretical spacing" as a miss. For the ISO Multiples index, the ISO Standard classifies "all spacing less than one-half times the theoretical spacing" as multiples. The Miss and Multiples indices are both expressed as percentages of the theoretical number of seed spacing. Seed distribution (laying precision) achieved in the laboratory on the sticky belt and in the field is divided into four spacing groups, of which $0,5 \div 1,5$ of the theoretical seed spacing $(3,5 \div 10,5 \mathrm{~cm})$ is relevant for drilling precision evaluation.

Table 1 In-row seed spacing distribution of red beet in the laboratory

\begin{tabular}{|c|c|c|c|c|c|c|}
\hline $\begin{array}{l}\text { Precision } \\
\text { drill }\end{array}$ & $\begin{array}{c}\text { Field } \\
\text { speed } / \mathrm{m} / \mathrm{s}\end{array}$ & $\begin{array}{l}\text { Theoretical seed } \\
\text { spacing } Z_{\mathrm{t}} / \mathrm{mm}\end{array}$ & $\begin{array}{l}\text { Single seed drops in the } \\
\text { range of }>0,5 Z_{t} \text { to } \leq 1,5 Z_{t} / \%\end{array}$ & $\begin{array}{c}\text { Multiples } \\
\text { index } x_{1} / \%\end{array}$ & $\begin{array}{l}\text { ISO Misses } \\
\text { index } x_{2} / \%\end{array}$ & $\begin{array}{c}\text { Misses } \\
\text { index } x_{3} / \%\end{array}$ \\
\hline $\begin{array}{l}1 \text { Belt feed } \\
(\mathrm{BF})\end{array}$ & $\begin{array}{l}0,83 \\
1,25 \\
1,44 \\
1,81\end{array}$ & 70 & $\begin{array}{l}88,1 \\
86,4 \\
78,2 \\
72,5 \\
\end{array}$ & $\begin{array}{l}5,6 \\
6,2 \\
6,9 \\
8,4\end{array}$ & $\begin{array}{c}6,3 \\
7,4 \\
14,0 \\
17,9\end{array}$ & $\begin{array}{l}0,0 \\
0,0 \\
0,9 \\
1,2\end{array}$ \\
\hline $\begin{array}{l}2 \text { Cell wheel feed } \\
\text { (CF) }\end{array}$ & $\begin{array}{l}0,83 \\
1,25 \\
1,44 \\
1,81\end{array}$ & 70 & $\begin{array}{l}89,3 \\
87,5 \\
79,1 \\
73,8\end{array}$ & $\begin{array}{l}5,2 \\
5,8 \\
7,1 \\
8,2\end{array}$ & $\begin{array}{c}5,5 \\
6,7 \\
13,8 \\
17,0\end{array}$ & $\begin{array}{l}0,0 \\
0,0 \\
0,0 \\
1,0\end{array}$ \\
\hline $\begin{array}{l}3 \text { Vacuum feed } \\
\text { (VF) }\end{array}$ & $\begin{array}{l}0,83 \\
1,25 \\
1,44 \\
1,81\end{array}$ & 70 & $\begin{array}{l}91,5 \\
88,2 \\
82,7 \\
75,4\end{array}$ & $\begin{array}{l}3,8 \\
4,1 \\
6,3 \\
8,2\end{array}$ & $\begin{array}{c}4,7 \\
5,6 \\
10,8 \\
15,9\end{array}$ & $\begin{array}{l}0,0 \\
0,0 \\
0,2 \\
0,5\end{array}$ \\
\hline $\begin{array}{c}4 \text { Pneumatic feed } \\
\text { with compressed } \\
\text { air }(\mathrm{PF})\end{array}$ & $\begin{array}{l}0,83 \\
1,25 \\
1,44 \\
1,81\end{array}$ & 70 & $\begin{array}{l}90,3 \\
87,8 \\
82,1 \\
74,6\end{array}$ & $\begin{array}{l}4,3 \\
4,9 \\
5,8 \\
8,3\end{array}$ & $\begin{array}{c}5,4 \\
6,5 \\
12,1 \\
16,4\end{array}$ & $\begin{array}{l}0,0 \\
0,8 \\
0,0 \\
0,7\end{array}$ \\
\hline
\end{tabular}

$x_{1}$ all spacings less than 0,5 theoretical seed spacing $Z_{\mathrm{t}} ; x_{2}$ all spacings larger than $1,5 Z_{\mathrm{t}}$ and less than $2,5 Z_{\mathrm{t}} ; x_{3}$ all spacings larger than $2,5 Z_{\mathrm{t}}$

Seeds laid in group $0,5 \div 1,5$ of the theoretical seed spacing are considered to be within the tolerated precision limits [19]. The multiples index (to $3,5 \mathrm{~cm}$ seed spacing) is considered less favourable, since in this group two seeds were often found in one space, so such plant density can be thinned after emergence. The least favourable was the group with spacing over 2,5 of the theoretical seed spacing (over 17,5 cm), misses index, since empty spaces were found in plant density. All the seeds are laid under the same conditions with respect to sowing depth and soil moisture. Depending on the intended use and climatic characteristics of the region, in-row seed spacing of 5 to $10 \mathrm{~cm}$ can be applied to red beet production. The set inrow seed spacing for all treatments with all metering mechanisms was $7,0 \mathrm{~cm}$ and the drilling depth was 1,5 $\mathrm{cm}$. Hybridred beet Kestrel F1 seed, single-germ, pelleted, calibre $3,2 \div 3,6 \mathrm{~mm}$ and $94 \%$ germination, was used in this research.

\section{Results}

The number of seeds that drilling mechanisms of the drills can discharge per unit of time, depends on the seed laying spacing within rows as well as on the drill operating speed. The multiples index (to $3,5 \mathrm{~cm}$ seed spacing) is considered less favourable, since in this group two seeds were often found in one space, so such plant density can be thinned after emergence. The least favourable was the group with spacing over 2,5 of the theoretical seed spacing (over 17,5 cm), misses index, since empty spaces were found in plant density. Results in the laboratory given in Tab. 1 show that drill 1 - BF, at operating speed of $0,83 \mathrm{~m} / \mathrm{s}$, achieved the seed distribution accuracy of $88,1 \%(3,5 \div 10,5 \mathrm{~cm})$ while the best seed distribution (91,5\%) was that of drill 3 - VF. Seed distribution quality diminished with increasing 
operating speed of all the tested drills, so the inferior results were obtained at the operating speed of $1,81 \mathrm{~m} / \mathrm{s}$. Most in-row seed spacing of 3,5 cm (multiples index) was observed at the operating speed of $1,81 \mathrm{~m} / \mathrm{s}$ with drill $1-$ BF $(8,4 \%)$ while least was observed at operating speed of $0,83 \mathrm{~m} / \mathrm{s}$ with drill $3-\mathrm{VF}(3,8 \%)$. At the operating speed of $1,81 \mathrm{~m} / \mathrm{s}$ drill $1-\mathrm{BF}$ sowed $1,2 \%$ seeds to the seed spacing over 2,5 of the theoretical seed spacing, while drill 2 - CF sowed $1,0 \%$ seeds. If all drills and all operating speeds are taken into consideration, it can be seen that the worse results were achieved with drill 1 $\mathrm{BF}$ and the best results with drill $3-\mathrm{VF}$ at all the operating speeds applied. At all the operating speeds, drill $4-\mathrm{PF}$ distributed seeds better than drills $1-\mathrm{BF}$ and 2 $\mathrm{CF}$, but worse than drill 3 - VF. Comparison of the results obtained with drills 1 and 2 shows that better results were achieved with drill 2 - CF. Laboratory drill testing served as a method for checking the results of drill testing under field conditions, the results of which are presented in Tab. 2. At the operating speed of $0,83 \mathrm{~m} / \mathrm{s}$, the best results $(83,1 \%)$ were achieved with drill $3-\mathrm{VF}$, and the worse results $(76,3 \%)$ with drill 1 - BF. In-row seed spacing distribution accuracy diminished with increasing operating speed of all the tested drills. Thus, at the speed of $1,81 \mathrm{~m} / \mathrm{s}$, drill 3 - VF discharged $70,3 \%$ seeds into the group $0,5 \div 1,5$ of the theoretical seed spacing, while drill 1 - BF sowed 63,4\% seeds. Most double spaces (13,5\%) were recorded for drill $1-\mathrm{BF}$ at the drilling speed of 1,81 $\mathrm{m} / \mathrm{s}$, and the $5,7 \%$ for drill 3 at the drilling speed of 0,83 $\mathrm{m} / \mathrm{s}$. Most double spaces $(13,5 \%)$ were recorded for drill 1 - BF at the drilling speed of $1,81 \mathrm{~m} / \mathrm{s}$, and the $5,7 \%$ for drill 3 at the drilling speed of $0,83 \mathrm{~m} / \mathrm{s}$.

Table 2 In-row seed spacing distribution of red beet in the field

\begin{tabular}{|c|c|c|c|c|c|c|}
\hline $\begin{array}{l}\text { Precision } \\
\text { drill }\end{array}$ & $\begin{array}{c}\text { Field } \\
\text { speed } / \mathrm{m} / \mathrm{s}\end{array}$ & $\begin{array}{l}\text { Theoretical seed } \\
\text { spacing } Z_{t} / \mathrm{mm}\end{array}$ & $\begin{array}{c}\text { Single seed drops in the } \\
\text { range of }>0,5 Z_{\mathrm{t}} \text { to } \leq 1,5 Z_{\mathrm{t}} / \%\end{array}$ & $\begin{array}{c}\text { Multiples } \\
\text { index } x_{1} / \%\end{array}$ & $\begin{array}{l}\text { ISO Misses } \\
\text { index } x_{2} / \%\end{array}$ & $\begin{array}{c}\text { Misses } \\
\text { index } x_{3} / \%\end{array}$ \\
\hline $\begin{array}{l}1 \text { Belt feed } \\
(\mathrm{BF})\end{array}$ & $\begin{array}{l}0,83 \\
1,25 \\
1,44 \\
1,81\end{array}$ & $2 \times$ & $\begin{array}{l}76,3 \\
71,8 \\
65,6 \\
63,4\end{array}$ & \begin{tabular}{|c|}
6,1 \\
8,0 \\
10,2 \\
13,5 \\
\end{tabular} & $\begin{array}{l}17,4 \\
19,7 \\
23,1 \\
20,8\end{array}$ & $\begin{array}{l}0,2 \\
0,5 \\
1,1 \\
2,3\end{array}$ \\
\hline $\begin{array}{c}2 \text { Cell wheel feed } \\
\text { (CF) }\end{array}$ & $\begin{array}{l}0,83 \\
1,25 \\
1,44 \\
1,81 \\
\end{array}$ & 70 & $\begin{array}{l}78,5 \\
75,9 \\
68,7 \\
64,6 \\
\end{array}$ & $\begin{array}{r}6,4 \\
7,7 \\
10,1 \\
12,6 \\
\end{array}$ & $\begin{array}{l}15,1 \\
16,3 \\
19,5 \\
20,6 \\
\end{array}$ & $\begin{array}{l}0,0 \\
0,1 \\
1,7 \\
2,2\end{array}$ \\
\hline $\begin{array}{l}3 \text { Vacuum feed } \\
(\mathrm{VF})\end{array}$ & $\begin{array}{l}0,83 \\
1,25 \\
1,44 \\
1,81 \\
\end{array}$ & 70 & $\begin{array}{l}83,1 \\
79,6 \\
75,8 \\
70,3 \\
\end{array}$ & $\begin{array}{c}5,7 \\
7,9 \\
9,4 \\
11,6 \\
\end{array}$ & $\begin{array}{l}11,1 \\
12,5 \\
14,1 \\
16,7 \\
\end{array}$ & $\begin{array}{l}0,1 \\
0,0 \\
0,7 \\
1,4\end{array}$ \\
\hline $\begin{array}{l}4 \text { Pneumatic eed with } \\
\text { compressed air }(\mathrm{PF})\end{array}$ & $\begin{array}{l}0,83 \\
1,25 \\
1,44 \\
1,81\end{array}$ & 70 & $\begin{array}{l}83,0 \\
77,5 \\
75,3 \\
68,6\end{array}$ & $\begin{array}{c}5,9 \\
7,6 \\
9,8 \\
12,1\end{array}$ & $\begin{array}{l}11,1 \\
14,3 \\
14,0 \\
17,7\end{array}$ & $\begin{array}{l}0,0 \\
0,6 \\
0,9 \\
1,6\end{array}$ \\
\hline
\end{tabular}

$x_{1}$ all spacings less than 0,5 theoretical seed spacing $Z_{\mathrm{t}} ; x_{2}$ all spacings larger than $1,5 Z_{\mathrm{t}}$ and less than $2,5 Z_{\mathrm{t}} ; x_{3}$ all spacings larger than $2,5 Z_{\mathrm{t}}$

Most double spaces (13,5\%) were recorded for drill 1 - BF at the drilling speed of $1,81 \mathrm{~m} / \mathrm{s}$, and $5,7 \%$ for drill 3 at the drilling speed of $0,83 \mathrm{~m} / \mathrm{s}$. In the spacing group over 2,5 (misses index), most seeds $(2,3 \%)$ were sown by drill $1-\mathrm{BF}$ at the speed of $1,81 \mathrm{~m} / \mathrm{s}$. Uniformity of seed distribution, depending on the type of drilling mechanism, indicated that pneumatic drilling mechanisms discharged seeds more precisely to the required in-row spacing compared to mechanical drilling mechanisms. This could be attributed to the better filling of holes on the drilling plate of pneumatic drilling mechanisms.

Comparison of the results presented in Tab. 1 and Tab. 2 show that better results were achieved in laboratory testing as opposed to drill tests in the field. The different results can be attributed to drive-wheel skidding and increased vibration of the whole machine, occurring during the field tests.

\section{Discussion}

Beetroot sowing with all the tested drills led to reduced plant density due to the occurrence of empty spaces. This plant density reduction was not linear; it was much faster at higher speeds. It was found that the set plant density is most easily achieved at the lowest speed $\left(0,83 \mathrm{~ms}^{-1}\right)$. The increased level of vibrations induced at the higher speed by soil surface roughness affects in-row seed spacing distribution accuracy, and is probably more effective on larger seeds than on smaller ones [13]. Fanigliulo and Pochi [13] noted that the working speed represents the main factor affecting the performances of the pneumatic precision drill, the field test results with 5,1 $\mathrm{km} / \mathrm{h}(1,42 \mathrm{~m} / \mathrm{s})$ and $8,2 \mathrm{~km} / \mathrm{h}(2,28 \mathrm{~m} / \mathrm{s})$ evidenced that at the higher speed sowing accuracy decreased for maize (147 mm seed spacing) and soya (52 $\mathrm{mm}$ seed spacing), but increased for sugar-beet (120 mm seed spacing). Ivančan et al. [20] indicated that the increase of operating speed in field condition leads to changes of the values of the drill performance indicators. The best intra-row distribution of parsley seeds was recorded at the speed of $1,8 \mathrm{~km} / \mathrm{h}(0,50 \mathrm{~m} / \mathrm{s})$. At this speed $80,4 \%$ of seed was sown at the required spacing. At $2,4 \mathrm{k} / \mathrm{m}(0,67 \mathrm{~m} / \mathrm{s}), 79,3$ $\%$ of seed was sown, $79,4 \%$ of seed at a speed of 3,6 $\mathrm{km} / \mathrm{h}(1,00 \mathrm{~m} / \mathrm{s})$, reducing to $76,6 \%$ at a speed of 5,2 $\mathrm{km} / \mathrm{h}(1,44 \mathrm{~m} / \mathrm{s})$. Kowalczuk and Zarajczyk [21]noted a negative correlation between coefficients of seeding quality and operating speed in both laboratory and field conditions, with the three operating speeds $(0,7 ; 1,0$ and $1,4 \mathrm{~m} / \mathrm{s}$ ) used. These tests for seeding carrots with precision drill (belt feed mechanism) indicated that best quality seeding results were achieved at the working speed of $0,7 \mathrm{~m} / \mathrm{s}$ [22]. Lammers et al. [23] tested the quality of precision seeders for sugar beets and indicated that the spacing accuracy fell slightly at a speed of more 
than $8 \mathrm{~km} / \mathrm{h} \quad(2,22 \mathrm{~m} / \mathrm{s})$. At a lower speed $6 \mathrm{~km} / \mathrm{h} \quad(1,67 \mathrm{~m} / \mathrm{s})$ the number of doubles was significantly smaller than at speeds of 8 or $10 \mathrm{~km} / \mathrm{h}(2,22$ or $2,78 \mathrm{~m} / \mathrm{s}$ ) also noting that a higher speed influences the number of misses negatively.

\section{Conclusion}

Homogenous cropstand with the least possible misses or doubles is heavily dependent upon the choice and adjustment of the right sowing machine as well as on the drill operating speed. The tests compared four precision drills for red beet under field conditions and in the laboratory. The test results with $0,83 \mathrm{~m} / \mathrm{s} ; 1,25 \mathrm{~m} / \mathrm{s} ; 1,44$ $\mathrm{m} / \mathrm{s}$ and $1,81 \mathrm{~m} / \mathrm{s}$ evidenced that at higher speeds, sowing accuracy decreased. Pneumatic drilling mechanisms laid seeds more precisely than mechanical drilling mechanisms. In comparing these two mechanisms, the best results were reached with vacuum feed mechanism and the worst results with the belt feed mechanism.

\section{References}

[1] Lešić, R.; Borošić, J.; Buturac, I.; Ćustić, M.; Poljak, M.; Romić, D. Povrćarstvo. Zrinski, Čakovec, 2002.

[2] Goldman, I. L.; Navazio, J. P. History and breeding of table beet in the United States. // Plant Breeding Reviews. 22, (2003), pp. 357-388.

[3] Chapter 6 Beet. // Genome Mapping and Molecular Breeding in Plants, Volume 5 Vegetables / McGrath, J.M.; Saccomani, M.; Stevanato, P.; Biancardi, E. In: C. Kole (ed.) Springer-Verlag, Berlin, 2007, pp. 191-207.

[4] Irving, D.; Boulton, A.; Wade, S. Beetroot Stand Management, New South Wales Department of Primary Industries, Yanco Agricultural Institute, Bathurst Primary Industries Centre, Project Number: VG06117, Horticulture Australia Ltd, Sydney NSW 2000, 2012.

[5] Benjamin, L. R.; Sutherland, R. A.; Senior, D. The influence of sowing rate and row spacing on the plant density and yield of red beet. // The Journal of Agricultural Science. 104, (1985), pp. 615-624. DOl: 10.1017/S0021859600044397

[6] Brunotte, J. Einzelkornsaat von Rüben-Anforderungen und vergleichende Untersuchungen von Druckrollen. // Landtechnik. 3, (1986), pp. 128-136.

[7] Griepentrog, H. W. Seed distribution over the area. // EurAgEng. 98-A-059, Oslo. 1998.

[8] Schmitz, S. Aktueller Stand der Einzelkornsätechnik. // Zuckerrübe. 50, 1(2001), pp. 22-27.

[9] Hempsch, K.; Brinkmann, W. Pneumatische oder mehanische Einzelkornsägeräte für Zuckerrübenproduktion, 1985.

[10] Bracy, R. P.; Parish, R. L. Seeding uniformity of precision seeders. // Hort Tehnology. 8, (1998), pp. 182-185.

[11] Brinkmann, W. Welche Anlage ist bei Monogermsaatgut empfehlenswert? // Zuckerrüben Journal. 2, (1985), pp. 5662.

[12] Ivančan, S.; Sito, S.; Fabijanic, G. Analysis of the Performance of the Mechanical Drilling Unit in Sowing Vegetable. // Strojarstvo. 43, 4-6(2001), pp. 183-190.

[13] Fanigliulo, F.; Pochi, D. Air-Flow Distribution Efficiency of a Precision Drill Used in the Sowing of Different Graded Seeds. // Journal of Agricultural Science and Technology B. 1, (2011), pp. 655-662.

[14] Matotan, Z. Proizvodnja povrća, Globus, Zagreb, 1994.
[15] Labowsky, H. J. Richtlinien für DLG-Prüfungen von Einzelkornsämaschinen, Deutschen Landwirtschafts Gesellschaft, Grosumstand, 1996.

[16] Buzenkov, V.; Brandt, H. Vibros semjan rotacionnimi aparatami sejalok točnoga viseva. // Mehanizacija i elektrifikacija seljskogo hozjajstva. 3(1970), pp. 47-52.

[17] Kromer, K. H. Fortschritte bei den Systemtechniken für den Anbau und Ernte von Zuckerrüben. // Confederation Internationale des Betteraviers Europeens, XXXVII Kongress / June 1998, pp. 1-12.

[18] International standard ISO. Sowing equipment, Test methods, Part 1: single seed drills (precision drills) Geneve, Switzerland, 7256/1, 1984.

[19] DLG - Prüfberichte. Einzelkornsämaschine, Deutschen Landwirtschafts Gesellschaft, Gruppe 5a/60, Frankfurt am Main, 1999.

[20] Ivančan, S.; Sito, S.; Fabijanic, G. Effect of Precision Drill Operating Speed on the Intra-row Seed Distribution for Parsley. // Biosystems Engineering. 89, 3(2004), pp. 373 376. DOI: 10.1016/j.biosystemseng.2004.07.007

[21] Kowalczuk, J.; Zarajczyk, J. Comparing the quality of carrot seeds sowing by means of S011 Alex seeder in laboratory and field conditions. // Inżynieria Rolnicza. 3(2006), pp. 127-133.

[22] Kowalczuk, J.; Zarajczyk, J. Quality assessment of carrot seeding using precision belt seeder S011 Alex. // TEKA Kom. Mot. Energ. Roln. 6, (2006), pp. 41-45.

[23] Schulze Lammers, P.; Schmittmann, O.; Ziegler, K.; Göbel, E. Test of quality of precision seeders for sugar beets under field conditions, Actual Tasks on Agricultural Engineering. // Proceedings of the 42nd International Symposium on Agricultural Engineering / Opatija, 2014, pp. 13-123.

\section{Authors' addresses}

Nikola Bilandžija, PhD, Assistant Prof. University of Zagreb Faculty of Agriculture, Department of Agricultural Engineering, Svetošimunska cesta 25, 10000 Zagreb, Croatia E-mail: nbilandzija@agr.hr

Goran Fabijanić, mag. ing. agr., Expert Associate University of Zagreb Faculty of Agriculture, Department of Agricultural Engineering, Svetošimunska cesta 25, 10000 Zagreb, Croatia E-mail: gfabijanic@agr.hr

Stjepan Sito, PhD, Associate Prof. University of Zagreb Faculty of Agriculture, Department of Agricultural Engineering, Svetošimunska cesta 25, 10000 Zagreb, Croatia E-mail: ssito@agr.hr

Darko Kiš, PhD, Associate Prof.

Josip Juraj Strossmayer University of Osijek, Faculty of Agriculture in Osijek, Institute of Mechanization, Kralja Petra Svačića 1d, 31000 Osijek, Croatia E-mail: dkis@pfos.hr 